ISSN: $1412-1212$

\title{
THE Llfinniners
}

Economic, Business, Management, and Information System Journal

Volume 8, Nomor 1, Maret 2007

Subcenter Publikasi Ilmiah bidang Ekonomi Universitas Bina Nusantara

\begin{tabular}{l}
\hline Redaktur Utama \\
Dewan Redaksi
\end{tabular}

Engkos Achmad Kuncoro, S.E., M.M.

Dr. Harjanto Prabowo, M.M.

Idris Gautama So, SE., S.Kom., M.M., M.B.A.

Ersa Tri Wahyuni, S.E., M.Acc.

Tjia Fie Tjoe, S.Kom., M.M.

Misbahul Munir, Ak., M.B.A.

Parulian Sihotang, Ak., M.Acc., DipRes., Ph. D

Rindang Widuri, S.Kom., M.M.

Mitra Bestari

Editor Bahasa dan Setter

Sekretariat

Alamat Sekretariat

ISSN
Muhammad Nashihin, Ph.D.

Djoko Sigit Sayogo, S.E., M.Acc.

Tomy Gurtama Soemapradja, S.E., M.M.

Synthia Atas Sari, S.IP., M.Si.

Ariefah Rachmawati, S.Kom., M.M.

Anderes Gui, S.Kom., SE., M.M.

Retno Dewanti, S.IP., M.M.

Dra. Endang Ernawati, M.Lib.

Titik Rahayu S., S.S.

Holil

Angga Ferdiansyah

Hery H.M., S.Kom.

Lies Heliana

Subcenter Publikasi Ilmiah Bidang Ekonomi, Center for Research and Comunnity Services, Universitas Bina Nusantara

Jl. Kemanggisan Ilir III No. 45, Kemanggisan/ Palmerah, Jakarta Barat 11480

Telp. (021) 5327630 ext. 6129 Fax. (021) 5300244

e-mail: heryhm@binus.ac.id

1412-1212 
ISSN: $1412-1212$

THE UHinniners

Economic, Business, Management, and Information System Journal

Volume 8, Nomor 1, Maret 2007

\section{DAFTAR ISI}

Ignatius Sarto Kothson Budiman

Analisis Hubungan Profitabilitas dengan Harga Saham Sektor Usaha Makanan

dan Minuman di Bursa Efek Jakarta

(Analysis of Profitability Relations with Stock Price in Foods and Beverages

Business Sector in Jakarta Stock Exchange)

Synthia Atas Sari; Hartiwi Prabowo

Peran Growth Opportunities, Free Cash Flow, dan Relative Issue Size

dalam Reaksi Pasar terhadap Pengumuman Right Issue

(The Role of Growth Opportunities, Free Cash Flow, and Relative Issue Size

in Market Reaction on the Right Issue Announcement).

Tomy Gurtama S.; Mesha

Analisis Kinerja Reksa Dana Nusantara PT Bhakti Asset Management

dan Penyusunan Portfolio Optimum Teoritis Periode Januari - April 2005

(Performance Analysis of Reksa Dana Nusantara of PT Bhakti Asset Management

and Constructing Theoritical Optimum Portfolio Period of Januari - April 2005).

\section{Antonius Herusetya}

Pendapat Auditor atas Laporan Keuangan untuk Perusahaan yang Terdaftar

di Bursa Efek Jakarta

(Auditor's Opinion on Financial Report for Listed Company in Jakarta Stock Exchange).

\section{Suryadiputra Liawatimena}

Analisis dan Perencanaan Konsep Strategi Content Management Cyberwoman

pada Situs Portal CBN.Net.Id

(Analysis and Planning of Cyberwoman Content Management Strategic Concept

on CBN.Net.Id Portal Site).

Hartiwi Prabowo; Synthia Atas Sari; Idris Gautama

Analisis Pemilihan Atribut Produk Baru untuk Perilaku Keputusan Pembelian Konsumen pada Produk Biokos Botu-Like Series

(Analysis of New Product Atribute Choosing for the Customer Buying Decision Behavior on Biokos Botu-Like Series Product)

\section{Henny Hendarti}

Model Pencatatan Intellectual Capital dalam Menghadapi Perubahan

Paradigma Akuntansi Baru

(Intellectual Capital Record Model in Facing the Changes of New Accounting Paradigm)... 